\title{
PENGARUH DIMENSI EKUITAS MEREK TERHADAP MINAT BELI PADA KERTANEGARA GUEST HOUSE MALANG
}

\author{
Ervan Ade Wardani \\ Department of Management FEB UMM \\ E-mail: ervanwardani@gmail.com
}

\begin{abstract}
Intention this research is to test dimension of equity brand have an effect to enthusiasm buy at Guest House Kertanegara Malang and to test brand equity influence to enthusiasm buy at Guest House. Population in this research are guest using service of Guest House Kertanegara, by using technique of convenience purposive sampling. Sample size 100 respondents. Technique analysis is linear regression analysis by using test of regression doubled linear. The result of research show that linear regression analysis is positive relationshio between the brand equity and enthusiasm., test t test and fest, indicating that brand equity have influence of significant to enthusiasm buy. Between awareness brand, brand association, perception of quality, dimension brand and loyality owning most influence significan is awareness of brand, brand association, perception of quality of, and brand loyality.
\end{abstract}

Keyword: Awareness of brand, brand association, perception of [is quality of, and brand loyalitas, enthusiasm buy.

\section{PENDAHULUAN}

Merek yang kuat dapat membantu perusahaan untuk mempertahankan identitas dari perusahaan tersebut (Aaker, 1996). Ekuitas merek merupakan hasil dari persepsi konsumen yang dipengaruhi oleh beberapa faktor. Kegiatan pemasaran yang dilakukan oleh perusahaan pun juga akan mempengaruhi persepsi konsumen mengenai suatu merek dari sebuah perusahaan. Persepsi ini pun juga akan mempengaruhi minat atau keputusan pembelian dari seorang konsumen (Sondang, 2013).

Adapun merek akan menjadi sumber daya saing yang bisa berlangsung lama dan bisa menjadi penghasil arus kas bagi perusahaan dalam jangka panjang. Produk yang memiliki merek yang kuat akan sulit ditiru karena persepsi konsumen atas nilai suatu merek tertentu tidak akan mudah diciptakan. Dengan ekuitas merek (brand equity) yang kuat, konsumen yang memiliki persepsi akan mendapatkan nilai tambah dari suatu produk yang tak akan didapatkan dari produk- produk lainnya. Menurut Aaker ( 2008 :23), ekuitas merek (brand equity) merupakan seperangkat aset dan liabilitas merek yang berkaitan dengan suatu merek, nama, dan simbolnya, yang menambah atau mengurangi nilai yang diberikan oleh sebuah barang atau jasa kepada perusahaan atau para pelanggan perusahaan (Alamsyah, 
2012).

Ekuitas merek yang diyakini oleh konsumen mengenai suatu merek sangat bervariasi tergantung dari persepsi masing-masing individu, kepribadian manusia pada umumnya ditentukan melalui nilai dan keyakinan yang mereka miliki. Apabila merek suatu produk memiliki image yang positif dan diyakini dapat memenuhi kebutuhan dan keinginannya, maka minat untuk membeli suatu produk atau jasa akan timbul dalam diri manusia. Sebaliknya apabila brand atau merek suatu produk atau jasa memiliki image negatif maka minat beli konsumen terhadap produk atau jasa tersebut akan rendah. Ekuitas merek yang positif berkaitan dengan kesetiaan konsumen, kepercayaan konsumen mengenai nilai merek yang positif, dan kesediaan untuk mencari merek tersebut (Haryanto, 2012).

Persepsi kualitas (perceived quality)mencerminkan persepsi pelanggan terhadap keseluruhan kualitas/keunggulan suatu produk atau jasa layanan berkenaan dengan maksud yang diharapkan (Durianto, 2004). Ekuitas merek yang tinggi akan memberikan keunggulan bersaing bagi suatu merek atau produk guna membentuk minat mereferensi. Karena ekuitas merek adalah nilai dari nama merek maka hubungan loyalitas merek (brand loyalty), asosiasi merek (brand associations) dan kesadaran merek (brand awareness) merupakan salah satu faktor yang mempengaruhi minat dalam menggunakan fasilitas penginapan (Indriyani, 2013).

Ekuitas merek yang dikelola dengan baik dapat membantu mempermudah persaingan bisnis dapat dimenangkan bagi perusahaan. Lingkungan bisnis yang dinamis serta konsumen yang semakin pintar memnuntut kesempurnaan strategi bersaing. Dengan melihat minat beli konsumen merupakan hal penting, maka penggelolaan dimensi-dimensi ekuitas merek perlu diperhatikan agar minat beli konsumen dapat terbentuk diantara merek-merek pesaing dalam lingkungan bisnis yang sejenis.

Guest House Kertanegarayang berada di kota Malang. Penginapan kelas menengah atas yang berada di pusat kota Malang ini kerap digunakan untuk acara meeting, bussines maupun acara keluarga dan pribadi. Promosi penjualannya seringkali dilakukan adalah melalui media internet dan media cetak maupun brosur. Dalam promosi penjualannya di desain untuk dapat menyampaikan ekuitas merek dan kualitas dari Guest House Kertanegara sendiri. Harga yang tertera pun juga diharapkan mampu untuk menggambarkan tingkat kualitas yang diberikan sesuai dengan pengorbanan yang dilakukan pelanggan.

Peranan dimensi dari eukuitas merek ini cukup penting bagi Guest House Kertanegara. Brand awareness ini menentukan sejauh mana konsumen mengenal pengnapan premium tersebut atau tidak. Brand association menentukan bagaimana penginapan ini dikenal di kalangan masyarakat. Perceived quality ini adalah persepsi yang dimiliki oleh konsumen mengenai pelayanan yang diberikan. Brand loyalty ini menetukan kesetiaan konsumen terhadap Guest House Kertanegara. Dari keempat dimensi ini, pengaruh mana yang diberikan cukup untuk dapat menimbulkan minat beli konsumen untuk menginap di guest house kertanegara.

Berdasarkan latar belakang di atas maka rumusan masalah dalam 
penelitian ini dapat diuraikan sebagai berikut: Bagaimanakah tanggapan konsumen tentang dimensi ekuitas merek pada Kertanegara Guest House Malang? Bagaimana minat beli konsumen Kertanegara guest house? Apakah dimensi ekuitas merek berpengaruh terhadap minat beli pada Kertanegara Guest House Malang? Dimensi ekuitas merek apakah yang mempunyai pengaruh terbesar terhadap minat beli pada Kertanegara Guest House Malang?

\section{TINJAUAN PUSTAKA}

Ekuitas merek adalah seperangkat asset dan liabilitas merek yang berkaitan dengan suatu merek, nama dan simbolnya yang menambah atau mengurangi nilai yang diberikan oleh suatu barang dan jasa kepada perusahaan atau pelanggan Aaker (2001:165). Aaker (1996) mengungkapkan bahwa ekuitas merek menciptakan nilai, baik pada perusahaan maupun pada konsumen. Pernyataan ini telah didukung oleh beberapa penelitian, diantaranya yang dilakukan oleh Smith et al (2007), yang menyatakan bahwa ekuitas merek dapat menjadi pertimbangan perusahaan dalam melakukan merger atau akuisisi Aset atau liabilitas yang mendasari ekuitas merek harus dihubungkan dengan nama dan atau simbol dari merek. Jika nama merek atau simbol diubah, beberapa atau keseluruhan dari aset atau liabilitas dapat dipengaruhi bahkan hilang, walaupun beberapa mungkin diganti dengan nama atau simbol baru. Menurut Aaker (1996), aset dan liabilitas dapat dikelompokkan dalam lima kategori, yaitu kesadaran merek (Brand Awareness), asosiasi merek (Brand Association), persepsi kualitas (Perceived Quality), loyalitas merek
(Brand Loyalty), Aset-aset hak milik yang lain, mewakili aset seperti paten, dan saluran distribusi. Keempat variabel ekuitas merek diluar aset-aset merek yang lain dikenal sebagai variabel utama dari ekuitas merek.

Britania Ready Reference (2004), kata minat berasal dari bahasa Inggris "interest" yang memiliki makan perasaan yang muncul bersamaan atau menyebabkan suatu perhatian khusus pada suatu objek atau kelompok objek. Dapat juga diartikan sebagai sesuatu yang memunculkan sebuah perhatian. Minat timbul karena pengalaman individu yang memuaskan dan bila minat telah terbentuk pada diri individu makan akan cenderung untuk menetap sepanjang obyek minat obyektif bagi individu Mouly dalam Atkinson (2007). Selanjutnya, Jones menyatakan bahwa minat sebagai sesuatu perasaan suka pada suatu benda atau situasi yang dapat diwujudkan dalam bentuk reaksi yang nyata atau hanya berupa organ-organ saja (Atkinson, 2007), sedangkan Marx berpendapat bahwa minat seseorang diikuti perasaan senang dan kecenderungan mencari obyek yang disenangi itu (Atkinson, 2007).

Dari beberapa pengertian atau definisi di atas, minat merupakan suatu kekuatan yang bersifat intirinsik yang mampu mendorong, mempengaruhi atau menyebabkan seorang individu dapat tertarik perhatiannya pada sesuatu di luar dirinya secara sadar. Minat juga dipandang sebagai suatu respon yang disadari dan mempunyai arah pada suatu obyek atau situasi tertentu yang menimbulkan rasa tertarik, dan individu lebih fokus perhatiannya pada obyek atau situasi tersebut daripada lainnya. Disamping itu, minat juga akan melibatkan kesediaan individu untuk berinteraksi dengan obyek atau situasi 
yang menimbulkan rasa senang pada dirinya.

Buying intention juga dapat diartikan sebagai rasa tertarik yang menimbulkan suatu dorongan untuk membeli produk tertentu. Seseorang mempunyai keinginan untuk membeli akan menunjukkan perhatian dan rasa tertarik terhadap produk tersebut. minat membeli ini akan diikuti dengan suatu tindakan berupa perilaku membeli. Jadi, disini minat membeli belumlah diikuiti suatu tindakan untuk membeli, namun hanyalah keinginan untuk membeli. Keputusan membeli sendiri dibentuk oleh individu setelah melakukan proses kognitif yang melibatkan minat, perhatiam, memori, persepsi, membuat alasan, penilaian, membayangkan dan berpikir (Microsoft Encarta, 2004). Apabila konsumen mempunyai minat untuk membeli suatu barang, maka konsumen tersebut akan menunjukkan sikap positif dan perasaan senang terhadap barang tersebut, sehingga konsumen akan memanifestasikan minat tersebut dengan perilaku membeli. Hal ini sejalan dengan yang dikatakan Engel, Blackwell, dan Miniard (2006), bahwa minat konsumen untuk membeli barang akan terealisasi dengan perilaku membeli.

Suntantio (2004:252) dalam Kuntjara (2007:28) mendeskripsikan minat pembelian sebagai kemungkinan pembeli berminat untuk membeli suatu produk.suntantio pun mengartikan buying intention sebagai peryataan yang berkaitan dengan batin yang mencerminkan rencana dari pembeli untuk membeli suatu merek tertentu dalam suatu periode waktu tertentu. Ferdinand (2002:129) dalam Kuntjara (2007:28) menyatakan bahwa indicator minat beli diantaranya adalah minat transaksional, yaitu kecenderungan seseorang untuk membeli produk. Minat referensial, yaitu kecenderungan seseoran untuk mereferensikan produk kepada orang lain. Minat preferensial, yaitu minat yang menggambakan perilaku seseorang yang mmeliki preferensi utama pada produk tersebut, preferensi ini dapat berubah bila terjadi sesuatu dengan produk preferensinya

Minat ekploratif, minat ini menggambarkan perilaku seseorang yang selalu mencari informasi mengenai produk yang diminatinya dan mencari informasi untuk mendukung sifat-sifat positif dari produk tersebut.

\section{METODE PENELITIAN}

Jenis penelitian ini dilakukan dengan menggunakann metode kausal. Penelitian ini digunakan untuk mengetahui seberapa besar pengaruh dimensi ekuitas merek terhadap minat beli konsumen di Kertanegara Guest House. Populasi penelitian ini adalah semua tamu yang menggunakan jasa dari Guest House Kertanegara. Penelitian kali ini menggunakan sampel dengan kriteria responden pria atau wanita, responden dengan rentang usia antara $23-55$ tahun. Pada rentang usia ini, responden dianggap dapat memberikan pendapat dan penilaian secara bijak. Jumlah responden 100 orang.

Penelitian ini bertujuan untuk mengetahui seberapa besar pengaruh ekuitas merek yang meliputibrand awareness, brand association, perceived quality, brand loyalty terhadap minat beli konsumen. "Regresi Linear Berganda" digunakan untuk mengetahui besarnya variabel bebas (X) terhadap variabel terikat (Y). rumus Regresi Linear Berganda adalah:

$Y=a+b_{1} X_{1}+b_{2} X_{2}+b_{3} X_{3}+b_{4} X_{4}$ 
Dimana $Y$ adalah Minat beli (dependen), a adalah konstanta,$X_{1}$ adalah brand awareness (independen), $X_{2}$ adalah brand association (independen) $X_{3}$ adalah perceiced quality (independen), $X_{4}$ adalah brand loyalty (independen), $\quad b_{1}$ adalah koefisien regresi $\mathrm{X}_{1}, b_{2} \quad$ adalah koefisien regresi $\mathrm{X}_{2}, b_{3} \quad$ adalah koefisien regresi $\mathrm{X}_{3}, b_{4} \quad$ adalah koefisien regresi $\mathrm{X}_{4}$.

\section{HASIL PENELITIAN DAN PEMBAHASAN}

Perhitungan regresi linier berganda untuk memprediksi besarnya variabel terikat terhadap variabel bebas. Persamaan regresi yang digunakan yaitu sebagai berikut:

$$
\begin{aligned}
& \mathrm{Y}=0,152+0,215 \mathrm{X}_{1}+0,354 \mathrm{X}_{2}+ \\
& 0,137 \mathrm{X}_{3}+0,090 \mathrm{X}_{4+\mathrm{e}}
\end{aligned}
$$

Dari Tabel 1, maka secara parsial masing-masing variabel bebas berpengaruh terhadap minat beli $(\mathrm{Y})$. Dengan koefisien sebagai berikut:

$\mathrm{a}=0,152$ merupakan nilai konstanta, yaitu estimasi dari minat beli, jika variabel bebas yaitu brand awareness, brand association, perceived quality dan brand loyalty mempunyai nilai sama dengan nol. $\mathrm{b}_{1}=0,215$ merupakan slope atau koefisien arah variabel brand awareness $\left(\mathrm{X}_{1}\right)$ yang mempengaruhi minat beli (Y), artinya variabel brand awarenessberpengaruh positif sebesar $21,5 \%$ terhadap minat beli, jika variabel lainnya dianggap konstan. Hasil tersebut menunjukkan bahwa dengan semakin baiknya brand awareness dalam hal ini mengenai Konsumen mengetahui merek Kertanegara Guest House, Konsumen dapat mengenali merek Kertanegara Guest House di antara merek-merek pesaing, konsumen dapat mengingat merek Kertanegara Guest Housetanpa harus melihat produknya dan Konsumen dapat menyebutkan merek Kertanegara Guest House bila produk dari merek Kertanegara Guest House disebut maka minat beli akan mengalami peningkatan. $b_{2}=0,354$ merupakan slope atau koefisien arah variabel brand association $\left(\mathrm{X}_{2}\right)$ yang mempengaruhi minat beli (Y), artinya variabel brand association berpengaruh positif sebesar $35,4 \%$ terhadap minat beli, jika variabel lainnya dianggap konstan. Hasil tersebut menunjukkan bahwa dengan semakin baiknya brand association dalam hal ini mengenai merek Kertanegara Guest House kuat dibenak konsumen, merek Kertanegara Guest House terkenal, Merek Kertanegara Guest House unik dan Merek Kertanegara Guest House mampu menggambarkan Kesan kualitas yang dimiliki maka minat beli akan mengalami peningkatan. $b_{3}=0,137$ merupakan slope atau koefisien arah variabel perceived quality $\left(\mathrm{X}_{3}\right)$ yang mempengaruhi minat beli (Y), artinya variabel perceived qualityberpengaruh positif sebesar $13,7 \%$ terhadap minat beli, jika variabel lainnya dianggap konstan. Hasil tersebut menunjukkan bahwa dengan semakin baiknya perceived quality dalam hal ini menganggap pelayanan Kertanegara Guest House berkualitas tinggi, Kemungkinan kualitas pelayanan Kertanegara Guest Housesangat tinggi, Kemungkinan bahwa pelayanan Kertanegara Guest House memiliki tingkat standart sangat tinggi dan pelayanan Kertanegara Guest Housepasti berkualitas sangat baguna maka minat beli akan mengalami peningkatan. $\mathrm{b}_{4}=0,090$ merupakan 
slope atau koefisien arah variabel brand loyalty $\left(\mathrm{X}_{4}\right)$ yang mempengaruhi minat beli (Y), artinya variabel brand loyaltyberpengaruh positif sebesar $9 \%$ terhadap minat beli, jika variabel lainnya dianggap konstan. Hasil tersebut menunjukkan bahwa dengan semakin baiknya brand loyalt dalam hal ini mengenai rekomendasi pembeli, pembelian ulang dan komitment pembeli maka minat beli akan mengalami peningkatan.

$\mathrm{e}=$ merupakan nilai residu atau kemungkinan kesalahan dari model persamaan regresi, yang disebabkan karena adanya kemungkinan variabel lainnya yang dapat mempengaruhi variabel minat belitetapi tidak dimasukkan kedalam model persamaan.

Berdasarkan hasil analisis maka hasil uji F dapat disajikan pada Tabel 1.

Tabel 1. Hasil Uji F

\begin{tabular}{|c|c|}
\hline Hipotesis Penelitian & FTabel \\
\hline $\begin{array}{l}\text { Terdapat pengaruh } \\
\text { yang signifikan } \\
\text { secara serentak dari } \\
\text { variabel brand } \\
\text { awareness, brand } \\
\text { association, } \\
\text { perceived quality } \\
\text { dan brand loyalty } \\
\text { terhadap minat beli }\end{array}$ & $\begin{array}{ll}\text { Fhitun } & \mathrm{H}_{\mathrm{a}} \\
\mathrm{g}= & \text { diterima } \\
65,044 & / \mathrm{H} \\
\text { FTabel } & \text { ditolak } \\
=2,460 & \\
\text { Sig. F } & \\
=0,000 & \end{array}$ \\
\hline
\end{tabular}

Dari hasil analisis regresi berganda dengan menggunakan $\mathrm{Df}_{1}=4$ dan $\mathrm{Df}_{2}=145$ pada alpha sebesar 5\% diperoleh F Tabel sebesar 2,460 sedangkan $\mathrm{F}$ hitungnya diperoleh sebesar 65,044 sehingga dari perhitungan di atas dapat diketahui bahwa Fhitung > FTabel, sehingga $\mathrm{H}_{\mathrm{O}}$ ditolak dan $\mathrm{H}_{\mathrm{a}}$ diterima, dengan demikian dapat dikatakan bahwa secara serentak variabel brand awareness, brand association, perceived quality dan brand loyalty berpengaruh terhadap minat beli (Y). Artinya bahwa dengan semakin meningkatnya ekuitas merek maka minat beli konsumen akan mengalami peningkatan.

Pengaruh secara parsial dapat diuraikan sebagai berikut, Pengaruh variabel brand awareness $\left(\mathrm{X}_{1}\right)$ terhadap minat beli (Y). Dengan pengujian statistik diperoleh nilai t hitung sebesar 5,392, karena nilai thitung $>\mathrm{t}$ Tabel (5,392> 1,980) maka disimpulkan bahwa maka secara parsial variabel brand awareness $\left(\mathrm{X}_{1}\right)$ berpengaruh signifikan terhadap minat beli. Artinya yaitu dengan mengetahui merek kertanegara guest house, mengenali merek kertanegara guest house di antara merek-merek pesaing, mengingat merek kertanegara guest house tanpa harus melihat langsung dan dapat menyebutkan merek Kertanegara Guest House bila produk dari merek kertanegara guest house disebut maka minat beli konsumen akan meningkat. Pengaruh variabel brand association $\left(\mathrm{X}_{2}\right)$ terhadap minat beli (Y). Dengan pengujian statistik diperoleh nilai t hitung sebesar 5,689, karena nilai thitung > $\mathrm{t}$ Tabel $(5,689>$ 1,980) maka disimpulkan bahwa maka secara parsial variabel brand association $\left(\mathrm{X}_{2}\right)$ berpengaruh signifikan terhadap minat beli. Artinya yaitu bahwa merek Kertanegara Guest House kuat, merek Kertanegara Guest House terkenal, merek Kertanegara Guest House unik dan merek Kertanegara Guest House memiliki kesan kualitas yang terjamin maka minat beli konsumen akan meningkat.

Pengaruh variabel perceived quality $\left(\mathrm{X}_{3}\right)$ terhadap minat beli $(\mathrm{Y})$. 
Dengan pengujian statistik diperoleh nilai t hitung sebesar 3,275, karena nilai thitung > t Tabel $(3,275>1,980)$ maka disimpulkan bahwa maka secara parsial variabel perceived quality $\left(\mathrm{X}_{3}\right)$ berpengaruh signifikan terhadap minat beli. Artinya yaitu menganggap Kertanegara Guest House pelayanan Kertanegara Guest House berkualitas tinggi, memiliki kualitas pelayanan yang lebih baik dari pesaing, memiliki tingkat standart sangat tinggidan pelayanan Kertanegara Guest House pasti berkualitas sangat bagusmaka minat beli konsumen akan meningkat. Pengaruh variabel brand loyalty $\left(\mathrm{X}_{4}\right)$ terhadap minat beli (Y). Dengan pengujian statistik diperoleh nilai $\mathrm{t}$ hitung sebesar 2,348, karena nilai thitung $>\mathrm{t}$ Tabel $(2,348>1,980)$ maka disimpulkan bahwa maka secara parsial variabel brand loyalty $\left(\mathrm{X}_{4}\right)$ berpengaruh signifikan terhadap minat beli. Artinya yaitu dengan merekomendasikan keunggulan yang dimiliki Kertanegara Guest House kepada orang lain, menginap kembali dan tetap menggunakan fasilitas yang ditawarkan oleh Kertanegara Guest House maka minat beli konsumen akan meningkat.

Tabel 2. Standardized Coeficient Beta

\begin{tabular}{lc}
\hline \multicolumn{1}{c}{ Variabel } & $\begin{array}{c}\text { Standardized } \\
\text { Coeficient Beta }\end{array}$ \\
\hline Brand awareness & 0,338 \\
Brand association & 0,381 \\
Perceived quality & 0,178 \\
Brand loyalty & 2,348 \\
\hline
\end{tabular}

Adapun untuk mengetahui besarnya pengaruh variabel bebas terhadap variabel terikat maka dapat diketahui dari hasil perbandingan koefisien regresi masing-masing variabel.
Berdasarkan hasil koefisien regresi (b) masing-masing variabel brand loyaltymempunyai pengaruh dominan terhadap minat beli. Hal tersebut dikarenakan koefisien regresi (Standardized Coeffucients Beta) pada variabel tersebut mempunyai nilai terbesar jika dibandingkan dengan ketiga variabel yang lain.

Hasil analisis apat diketahui bahwa apabila konsumendapat mengenali dengan baik merek Kertanegara Guest Housedi antara merek - merek pesaing maka konsumen akan kecenderungan seseorang untuk menginap, mereferensikan merek Kertanegara Guest House kepada orang lain dan selalu mencari informasi mengenai produk akan lebih tinggi. Selanjutnya apabila konsumen dapat dengan baik mengingat merek Kertanegara Guest Housetanpa harus melihat produknya maka semakin tinggi keinginan untuk menginap, mereferensikan merek Kertanegara Guest House kepada orang lain dan selalu mencari informasi mengenai produk akan lebih tinggi. Selajutnya dengan semamin baiknya konsumen dapat menyebutkan merek Kertanegara Guest House bila produk dari merek Kertanegara Guest House disebut maka minat beli akan mengalami peningkatan yang ditunjukkan dengan adanya peningkatan untuk menginap, mereferensikan merek Kertanegara Guest House kepada orang lain dan selalu mencari informasi mengenai produk yang ditawarkan oleh Kertanegara Guest House.

Kesadaran merek dapat diartikan adalah kesanggupan seseorang calon pembeli untuk mengenali atau meningkat kembali bahwa suatu merek merupakan bagian dari kategori produk tertentu (Aaker, 1996: 90). Peran brand 
awareness dalam keseluruhan brand equity tergantung dari sejauh mana tingkatan kesadaran yang dicapai oleh suatu merek. Hal ini mmeberikan gambaran mengenai sejauh mana konsumen dapat melakukan pengingatan kembali akan merek sehingga dapat mendukung minat beli yang akan dilakukan. Hasil penelitian ini mendukung hasil penelitian terdahulu yang dilakukan oleh Agusli (2003) yang diperoleh hasil bahwa terdapat pengaruh yang signifikan antara brand awareness terhadap minat beli.

Merek Kertanegara Guest House mampu menggambarkan kesan kualitas yang dimiliki maka dapat meningkatkan minat beli konsumen.Hasil analisis juga menunjukkan bahwa apabila semakin baiknya kesan kualitas maka minat konsumen akan semakin tinggi yang ditunjukkan dengan adanya kecenderungan seseorang untuk menginap, mereferensikan merek Kertanegara Guest House kepada orang lain dan selalu mencari informasi mengenai produk. Hasil penelitian ini mendukung hasil penelitian terdahulu yang dilakukan oleh Agusli (2003) yang diperoleh hasil bahwa terdapat pengaruh yang signifikan antara brand associationterhadap minat beli.

Berdasarkan hasil analisis menunjukkan bahwa kesan kualitas merupakan bentuk persepsi pelanggan terhadap keseluruhan kualitas atau keunggulan suatu produk atau jasa layanan berkaitan dengan maksud yang diharapkan. Adanya anggapan konsumen bahwa pelayanan yang diberikan memiliki tingkat standar yang sangat tinggi maka dapat mencipkan minat beli konsumen yang ditunjukkan dengan adanya keinginan untuk menginap, merekomendasikan kepada orang lain dan berupaya untuk mendapatkan informasi mengenai keunggulan produk. Apabila dikaitkan dengan adanya jaminan atas kepastian pelayanan yang diberikan maka minat konsumen akan mengalami peningkatan. Peningkatan tersebut menjadikan minat beli konsumen juga mengalami peningkatan yang ditunjukkan dengan adanya keinginan tingginya keinginan untuk menginap, memiliki keinginan untuk mereferensikan merek dan selalu mencari informasi mengenai produk.

Secara keseluruhan dapat diektahui bahwa terdapat lima keuntungan kesan kualitas. Keuntungan pertama adalah alasan membeli. Kesan kualitas sebuah merek memberikan alasan yang penting untuk membeli. Hal ini mempengaruhi merek-merek mana yang harus dipertimbangkan, dan selanjutnya mempengaruhi mereka apa yang akan dipilih. Keuntungan kedua adalah diferensiasi. Artinya, suatu karakteristik penting dari merek adalah posisinya dalam dimensi kesan kualitas. Keuntungan ketiga adalah harga optimum dan memberikan pilihanpilihan di dalam menetapkan harga optimum (premium price).

Keuntungan keempat adalah meningkatkan minat para distributor. Keuntungan keempat ini memiliki arti penting bagi para distributor, pengecer serta berbagai saluran distribusi lainnya, karena hal itu sangat membantu perluasan distribusi. Keuntungan kelima adalah perluasan merek. Kesan kualitas dapat dieksploitasi dengan cara mengenalkan berbagai perluasan merek, yaitu dengan menggunakan merek tertentu untuk masuk ke dalam kategori produk baru. Beberapa hal atau keuntungan tersebut mendukung minat 
beli yang dilakukan oleh konsumen. Hasil penelitian ini mendukung hasil penelitian terdahulu yang dilakukan oleh Agusli (2003) yang diperoleh hasil bahwa terdapat pengaruh yang signifikan antara percevied quality terhadap minat beli.

Berdasarkan hasil analisis dapat diketahui bahwa terdapat pengaruh yang signifikan antara brand loyalty terhadap minat beli, dengan demikian dapat dikatakan bahwa dengan semakin meningkatnya brand loyalty maka minat beli konsumen juga akan mengalami peningkatan.Peningkatan brand loyalty tersebut dapat ditunjukkan dengan adanya rekomendasi pembeli yang selanjutnya dapat menentukan minat beli konsumen dalam hal ini yaitu semakin tingginya keinginan untuk menginap, memiliki keinginan untuk mereferensikan merek dan selalu mencari informasi mengenai produk. Indikator berikutnhya yaitu menginap kembali yang memberikan gambaran mengenai tinginya minat beli komsumen, dimana tingginya minat beli tersebut secara langsung menjadikan minat beli konsumen akan mengalami peningkatan. Adanya komitmen pembeli maka dukungan terhadap minat beli juga mengalami peningkatan dalam hal ini tetap menggunakan fasilitas yang ditawarkan oleh Kertanegara Guest House maka upaya untuk menciptakan minat beli juga mengalami peningkatan. Hasil analisis juga menunjukkan bahwa loyalitas adalah ukuran dari kesetiaan konsumen terhadap suatu merek. Loyalitas merek merupakan inti dari brand equitu yang menjadi gagasan sentral dalam pemasaran karena hal ini merupakan satu ukuran keterkaitan seorang pelanggan pada sebuah merek. Apabila loyalitas merek meningkat, maka kerentaan kelompok pelanggan dari serangan kompetitor dapat dikurangi. Hal ini merupakan suatu indikator dari brand equity yang berkaitan dengan perolehan laba di masa yang akan datang karena loyalitas merek secara langsung dapat diartikan sebagai penjualan di masa depan.Perusahaan yang memiliki basis pelanggan yang mempunyai loyalitas merek yang tinggi dapat mengurangi biaya pemasaran perusahaan karena biaya untuk mempertahankan pelanggan jauh lebih murah dibandingkan mendapatkan pelanggan baru. Menurut Griffen (2002:31) loyalitas pelanggan merupakan ukuran yang dapat diandalkan untuk memprediksi pertumbuhan penjualan dan keuangan.Hasil penelitian ini mendukung hasil penelitian terdahulu yang dilakukan oleh Agusli (2003) yang diperoleh hasil bahwa terdapat pengaruh yang signifikan antara brand loyalty terhadap minat beli.

\section{SIMPULAN}

Berdasarkan hasil dari uji $\mathrm{F}$, variabel ekuitas merek yang terdiri dari brand awareness, brand association, perceived quality, dan brand loyalty, secara simultan berpengaruh signifikan terhadap buying intention di Guest House Kertanegara Malang. Hal ini berarti model penelitian brand awareness, brand association, perceived quality, dan brand loyalty, terhadap buying interest di Guest House Kertanegara Malang sudah tepat. Berdasarkan hasil dari uji t dapat diketahui bahwa 1) Brand awareness memiliki pengaruh yang signifikan terhadap buying interest konsumen Guest House Kertanegara Malang. 2) Brand association memiliki pengaruh yang signifikan terhadap buying 
interestkonsumen Guest House Kertanegara Malang. 3) Perceived quality memiliki pengaruh yang signifikan terhadap buying interest konsumen Guest House Kertanegara Malang. 4) Brand loyalty memiliki pengaruh yang signifikan terhadap buying interest konsumen Guest House Kertanegara Malang. 5) Variabel yang memiliki pengaruh paling dominan terhadap buying interestadalah brand loyalty.

Berdasarkan dua kesimpulan di atas, dapat diketahui bahwa ekuitas merek dari Guest House Kertanegara Malang secara keseluruhan sudah baik. Masyarakat mengetahui keberadaan Guest House Kertanegara Malang sebagai salah satu business Guest Houseyang berada di Malang. Serta minat beli pada Guest House Kertanegara masuk dalam katagori tinggi, dimana minat beli yang tinggi ditunjukan dengan memberikan rekomendasi pembeli yang selanjutanya dapat menentukan minat beli konsumen, dalam hal ini yaitu semakin tingginya keinginan untuk menginap, memiliki keinginan untuk merefrensikan merek dan akan selalu mencari informasi mengenai produk yang dimiliki Guest House Kertanegara Malang.

\section{DAFTAR PUSTAKA}

Aaker, D. (1996). Building Strong Brands. New York: The Free Press.

Aaker, D. A. (1996). Measuring Brand Equity Across Product and Market.

California

Management Review, Vol 38 No. 3, 102-121.

Agusli, Sondang. 2013. Analisis Pengaruh Dimensi Ekuitas Merek Terhadap Minat beli pada Midtown Hotel Surabaya.
Jurnal Ekonomi Petra. Vol. 1 No. 2.

Alamsyah. 2013. Analisis Pengaruh Ekuitas Merek dan Kualitas pelayanan Terhadap Loyalitas Pelanggan. Jurnal Ekonomi Manajemen. Vol 3. 1 oktober.

Atkinson, A. F. (2007). Health, disability, caring, and employment : longitudinal anaysis. DWP Research.

Durianto, D., Sugiarto, \& Sitinjak, T. 2004. Strategi Menaklukkan Pasar Melalui Riset Ekuitas dan Perilaku Merek.Jakarta: PT. Gramedia Pustaka Utama

Engel, J., R. B. 2006. Perilaku Konsumen (Sucipto Trans). Jakarta: Binarupa Aksara.

Ferdinand. 2014. Metode Penelitian Kuantitatif. Universitas Diponegoro Semarang. Aerlangga.

Ghozali, Imam. 2011. Aplikasi Analisis Multivariate Dengan Program IBM SPSS 19 (edisi kelima.)Semarang: Universitas Diponegoro

H.B. Sutopo. 2006. Metodologi Penelitian Kualitatif: Dasar teori dan Terapannya dalam Penelitian Surakarta: Universitas Sebelas Maret.

Haryanto. 2012. Pengaruh Display, Kepercayaan Merek, Keakraban Merek Terhadap Itensitas Pembelian Tak Terencana. Universitas Kristen Setyawacana.

Hendra. 2013. Lokasi, Keberagaman produk, Harga dan Kualitas Layanan Terhadap Minat Beli. Universitas Samratu Langit Manado.

Keller, K. L. (2003). Strategic Brand Management. Prentice - Hall 
Kuntjara. 2007. Analisis Faktor-Faktor Yang Mempengaruhi Minat Beli Ulang Konsumen (Studi Kasus di PT. Wijaya Karya Beton Wilayah IV; Jateng, DIY, Kalsel dan Kalteng).Tesis di Universitas Diponegoro

Mulyana. 2012. Pengaruh Private Brand Strategi Terhadap Brand Loyalty pada Air Mineral Alfa Surabaya.

Mundir, 2012. Analisis Pengaruh Mutu Produk dan Persepsi Harga Terhadap Minat Beli. Universitas Diponegoro Semarang.

Rangkuti, F. (2004). The Power of Brands. Jakarta: PT. Gramedia Pustaka Utama

Sanusi, Anwar. 2003. Metodelogi Penelitian Praktis Untuk Ilmu Sosial dan Ekonomi. Malang: Buntara Media.

Silalahi, Ulbert. 2010. Metode Penelitian Sosial.Banfung: PT. Refika Aditama

Smith, D.J., N. G. (2007). An Analysis of Brand Equity Determinants: Gross Profit, Advertising, Research, and Development. Journal of Business and Economics Research Vol. 5 No. 11, $103-116$

Sugiyono. 2010.Metode Penelitian Bisnis. Bandung: Alfabeta.
Susanto A.B dan Wijanarko Himawan. 2004. Power Branding (Membangun Merek Unggul dan Organisasi Pendukungnya) Jakarta: PT Mizan Publika.

Sutopo, H.B. 2006. Penelitian Kuantitatif: Dasar Teori dan Terapannya Dalam Penelitian. Surakarta. Universitas Sebelas Maret.

Widjaja, M., Wijaya, S., dan Jokom, R., 2007, Analisis Penilaian Konsumen Terhadap Ekuitas Merek Coffee Shops di Surabaya. Jurnal Manajemen Perhotelan, Vol. 3 No. 2, 89 101.

Widyaningrum. 2011. Analisis Pengaruh Kualitas Produk, Harga dan Daya Tarik Iklan Terhadap Minat Beli Sepeda Motor Yamaha. Jurnal manajemen pemasaran.UNDIP Semarang

www. Ensiklopedia Britania Reference.com.

Yoo B., N. D. (2000). An Exemination

of Selected Marketing Mix Elements

and Brand Equity. Journal of Academy

of Marketing Science Vol. 28, No.22, $195-211$ 